\title{
単位容積質量と空気量からフレッシュコンクリート の単位水量を算定する方法に関する研究
}

\author{
中村博之 $1 \cdot$ 近松竜一 $1 \cdot$ 十河茂幸 2 \\ ${ }^{1}$ 正会員 工修 大林組技術研究所（％204-8558 東京都清瀬市下清戸4-640） \\ 2 フェロー会員 工博 大林組技術研究所（２04-8558 東京都清瀬市下清戸4-640）
}

\begin{abstract}
フレッシュコンクリートの単位容積質量と空気量の測定結果をもとに単位水量を算定する方法に 関して, 各種の誤差要因が算定結果に及ぼす影響を明らかにするとともに, 単位水量の推定精度に ついて検証した。 その結果, 細骨材や粗骨材の湿潤密度の設定誤差や空気量の測定誤差が単位水量 の算定值に及ぼす影響が大きいこと, 単位容積質量および空気量を精度良く求めることで計量誤差 やサンプリング誤差がない場合には単位水量を約 $\pm 2 \mathrm{~kg} / \mathrm{m}^{3}$ の範囲で推定できることを明らかにした. また, この方法は, 汎用のエアメー夕装置を用いること, 約5分と比較的迅速に測定できること, などから現場での簡便な単位水量評価方法として適用性が高いことを示した.
\end{abstract}

Key Words : water content, density of concrete, air content, air meter inspection

\section{1.はじめに}

最近では，コンクリート片の剥落事例を契機として, コンクリート構造物の耐久性に関する社会的関心が高 まり,コンクリートの品質をより適正に評価できる測定 技術の開発が要望されている.

コンクリートの配合要因のなかでも, 水セメント比や 単位水量は, コンクリート構造物の耐久性を左右する重 要な影響因子である. とりわけ, 塩化物イオンをはじめ とする外来劣化因子の浸透を促し, 構造物の耐久性を低 下させるひび割れの発生に関与する要因として, 単位水 量の影響が大きいことは周知のとおりである.

フレッシュコンクリートの単位水量に関しては, これ までに表-1 に示すような測定方法が提案されている.

これらの方法を測定原理毎に整理すると, (1)コンクリ 一ト構成材料の配合比, 質量や容積の差を利用する方法, (2)試料中の水量を蒸発させて直接抽出する方法, (3)試料 に特定の試薬を添加してその濃度変化から求める方法, (4)中性子線, 静電容量, 赤外線方式等の水分センサを応 用した方法, 等に分類される.

また, 測定試料の種類として, モルタルを試料とする 場合とコンクリートを試料として用いる場合に大別さ れる. モルタルを用いる場合には, コンクリートをウェ ットスクリーニングしてサンプルを採取する.この際,
スクリーニングの方法によっては材料構成比が変動し, 測定誤差を生じる可能性がある. 一方, コンクリートを 試料とする場合は, サンプル量が測定誤差に大きく影響 することになる. 試料の量が少ないと粗骨材とモルタル の構成比が変化し, サンプリング誤差が大きくなる.

表中に示した各文献によれば, 単位水量の測定精度に 関しては, $\pm 2 \sim 10 \mathrm{~kg} / \mathrm{m}^{3}$ あるいは $\pm 2 \sim 5 \%$ の範囲内に あるとされている. また, 測定時間に関しては, 約1分 とほぼリアルタイムで測定できるものから, 20〜30分以 上を要するものもある.

以上のように, 単位水量の測定に関しては, 各種の方 法が提案されているものの, これまでに荷卸し時の検査 として実際に行われることはほとんどなかった.これは, いずれの測定方法も測定時間, 測定装置の取扱い操作, 測定結果の信頼性などの点でそれぞれ一長一短があり， 現場での適用に際して実用性が十分に満足するものと なっていないためであり, 単位水量を簡便で, 迅速かつ 精度良く測定し, 検査項目として判定できる試験技術が 求められている.

本論文では, 現場で簡便に単位水量を試験できる方法 として, 単位容積質量と空気量から単位水量を算定する 方法を取り上げ, 各種誤差要因が算定結果に及ぼす影響 を明らかにするとともに, 単位水量の推定精度に関して 検証した結果を示すものである. 
表-1．フレッシュコンクリートの単位水量測定方法

\begin{tabular}{|c|c|c|c|c|c|}
\hline \multicolumn{2}{|r|}{ 試 験 方 法 } & 使用器具類 & 試料の種類・量 & 測定精度 & 測定時間 \\
\hline \multirow{4}{*}{$\begin{array}{l}\text { 構成材料 } \\
\text { 比·質量差· } \\
\text { 容積差法 }\end{array}$} & 絶対容積の差による方法1) & & $\begin{array}{l}\text { ウェットスクリーニング } \\
\text { モルタル } 0.4 \mathrm{~kg}\end{array}$ & & \\
\hline & \multirow[t]{2}{*}{$\begin{array}{l}\text { 空気中質量と水中質量 } \\
\text { の差による方法2) }\end{array}$} & 三角フラスコ & $\begin{array}{l}\text { ウェットスクリーニング } \\
\text { モルタル } 0.2 \mathrm{~L}\end{array}$ & $3 \%$ & 10 分 \\
\hline & & 水槽, かご & コンクリート & $\pm 4 \sim 6 \mathrm{~kg} / \mathrm{m}^{3}$ & 15 分 \\
\hline & 空気量試験による方法3),4) & $\begin{array}{l}\text { ワシントン型 } \\
\text { エアメータ }\end{array}$ & コンクリート:約 $16 \mathrm{~kg}$ & $\pm 5 \sim 10 \mathrm{~kg} / \mathrm{m}^{3}$ & 5分 \\
\hline \multirow{4}{*}{ 水抽出法 } & 一般加熱乾燥法5) & $\begin{array}{l}\text { ガスコンロ, 電熱器, } \\
\text { 赤外線乾燥器 }\end{array}$ & コンクリート:1L & $\pm 2 \%$ & $20 \sim 30$ 分 \\
\hline & 高周波誘電加熱乾燥法6) & 電子レンジ & $\begin{array}{l}\text { ウェットスクリーニング } \\
\text { モルタル:300〜 } 600 \mathrm{~g}\end{array}$ & $-5 \sim-0.5 \%$ & $10 \sim 20$ 分 \\
\hline & \multirow[t]{2}{*}{ 减圧乾燥法7) } & 减圧乾燥装置 & $\begin{array}{l}\text { ウェットスクリーニング } \\
\text { モルタル: } 400 \mathrm{~g}\end{array}$ & $4 \mathrm{~kg} / \mathrm{m}^{3}$ & 20分 \\
\hline & & 減圧乾燥装置 & コンクリート:約 $5 \mathrm{~L}$ & $\pm 2 \mathrm{~kg} / \mathrm{m}^{3}$ & 40分 \\
\hline \multirow{4}{*}{$\begin{array}{l}\text { 試薬濃度差 } \\
\text { 法 }\end{array}$} & アルコール比重計法1) & アルコール比重計 & コンクリート:約 $1 \mathrm{~L}$ & $\pm 5 \%$ 程度 & 20分 \\
\hline & \multirow{3}{*}{ 塩分濃度差法8).9) } & 塩分測定器 & コンクリート:約 $2 \mathrm{~L}$ & $\pm 3 \%$ & 20分 \\
\hline & & 電量滴定器 & コンクリート:約 $2 \mathrm{~kg}$ & $1.2 \%$ & 20 分以内 \\
\hline & & 滴定器 & コンクリート:7L & $4 \mathrm{~kg} / \mathrm{m}^{3}$ & $20 \sim 90$ 分 \\
\hline \multirow{3}{*}{ 水分計法 } & 静電容量測定法10) & 静電容量型水分計 & $\begin{array}{l}\text { ウェットスクリーニング } \\
\text { モルタル } 0.33 \mathrm{~L}\end{array}$ & $\pm 2.9 \sim 3.4 \%$ & 10分 \\
\hline & 中性子測定法11) & RI水分計 & コンクリート連続測定 & $2.7 \sim 3.2 \mathrm{~kg} / \mathrm{m}^{3}$ & 2分 \\
\hline & 赤外線測定法12) & $\begin{array}{l}\text { 光ファイバー式 } \\
\text { 赤外線水分計 }\end{array}$ & コンクリート:0.5L & $\pm 2 \mathrm{~kg} / \mathrm{m}^{3}$ & 40 秒 \\
\hline
\end{tabular}

\section{2. エアメータ法による単位水量測定方法の概要}

\section{（1）測定方法の原理}

コンクリートを構成する各材料の計量値が設定值と異 なる場合, コンクリートの単位容積質量にその結果が表 れる. 本論文で示す水量測定方法は，この原理をもとに， コンクリート中の単位水量を単位容積質量の設定と実測 の差から求めるものである.ただし，単位容積質量は， コンクリート中の空気量の増減によっても変化するので, 水量を正確に求めるには空気量の変動を補正する必要が ある. なお, 本方法では単位容積質量と空気量の測定に エアメータを用いるのでエアメータ法と呼ばれている3).

コンクリート製造時の材料の計量にあたっては，骨材 とりわけ細骨材の表面水変動が主な誤差要因と考えられ る.すなわち, 各材料とも見かけ上は設定どおり計量さ れているものの, 細骨材と一緒に計量される表面水量は 実際には設定と異なっている可能性があると考えられる.

本測定方法における前提条件を以下に示す.

(1)単位水量の増減は, 細骨材表面水の見込み違いによる.

(2)セメント, 粗骨材の計量值は既知である.

(3)使用材料の密度が既知である.

(4)測定試料は，コンクリートの代表サンプルである.

実際には，セメントの計量にはある程度の測定誤差が 生じ, 粗骨材の計量に関しても表面水率の設定誤差によ り表面水量の増減が生じる場合もあり得る. また, 単位

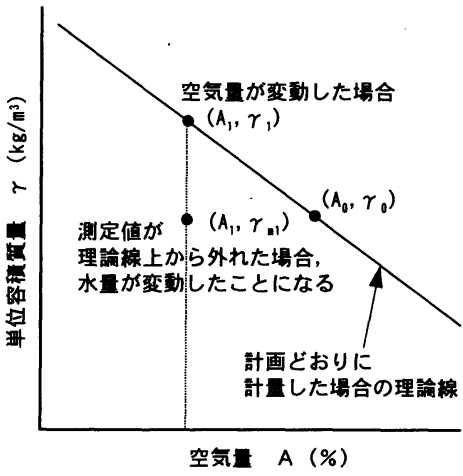

図-1 空気量と単位容積質量

水量の測定に際して, 試料が必ずしも代表サンプルとみ なせない可能性もあるが，本方法では，これらの誤差は ないものと仮定し, 細骨材表面水率の見込み違いを変動 要因として単位水量を算定する.

コンクリートの単位容積質量と空気量の関係について の模式図を図-1 に示す. 示方配合から求まるコンクリー トの単位容積質量を $\gamma_{0}$, 空気量の設定値を $\mathrm{A}_{0}$ とし, 仮に 空気量が $A_{1}$ に変動した場合の単位容積質量を $\gamma_{1}$ とする. 実際のコンクリートの空気量が $\mathrm{A}_{1}$ の場合に単位容積質 量の測定值 $\gamma_{\mathbf{m} 1}$ が $\gamma_{1}$ であれば計画どおりのコンクリート が製造されていると判定される． $\gamma_{\mathrm{al}}$ と $\gamma_{1}$ が相違する場 合は, 細骨材の表面水量に誤差が生じたことになる. 


\section{（2）単位水量の算定方法}

細骨材中の表面水量は, 通常は細骨材の質量の一部之 して計量している. したがって, 各材料の計量値を合計 したコンクリートの質量は見かけ上変化しないが，実際 には細骨材と水の密度差により容積が増隇し, その結果 として単位容積質量が変動することになる.

示方配合より, 以下の式(1), (2)が導かれる.

$$
\begin{aligned}
& \mathrm{W}_{0}+\mathrm{C}_{0}+\mathrm{S}_{0}+\mathrm{G}_{0}=\gamma_{0} \mathrm{~V}_{0} \\
& \frac{\mathrm{W}_{0}}{\rho \mathrm{w}}+\frac{\mathrm{C}_{0}}{\rho \mathrm{c}}+\frac{\mathrm{S}_{0}}{\rho \mathrm{s}}+\frac{\mathrm{G}_{0}}{\rho \mathrm{G}}+\mathrm{V}_{0} \cdot \frac{\mathrm{A}_{0}}{100}=\mathrm{V}_{0} \\
& \text { ここで, } \quad \mathrm{W}_{0}: \text { 水量の設定値 }(\mathrm{kg}) \\
& \mathrm{C}_{0}: \text { セメント量の設定值 }(\mathrm{kg}) \\
& \mathrm{S}_{0}: \text { 細骨材量の設定值 }(\mathrm{kg}) \\
& \mathrm{G}_{0}: \text { 粗骨材量の設定值 }(\mathrm{kg}) \\
& \gamma_{0}: \text { 単位容積質量の設定値 }\left(\mathrm{kg} / \mathrm{m}^{3}\right) \\
& \mathrm{V}_{0}: \text { コンクリート容積の設定値 }\left(\mathrm{m}^{3}\right) \\
& \rho_{\mathrm{w}}: \text { 水の密度 }\left(\mathrm{kg} / \mathrm{m}^{3}\right) \\
& \rho_{\mathrm{c}}: \text { セメントの密度 }\left(\mathrm{kg} / \mathrm{m}^{3}\right) \\
& \rho_{\mathrm{s}}: \text { 細骨材の表乾密度 }\left(\mathrm{kg} / \mathrm{m}^{3}\right) \\
& \rho_{\mathrm{G}}: \text { 粗骨材の表乾密度 }\left(\mathrm{kg} / \mathrm{m}^{3}\right) \\
& \mathrm{A}_{0}: \text { 空気量の設定値 }(\%)
\end{aligned}
$$

表面水率の見込み違いによる水の変動量を $\Delta \mathrm{W}_{\mathrm{s}}$ とし， 実際に製造したコンクリートの容積を $\mathrm{V}_{1}$ ，エアメータに よる単位容積質量および空気量の測定值をそれぞれ $\gamma$, および $\mathrm{A}_{1}$ とすると,

$$
\begin{gathered}
\left(\mathrm{W}_{0}+\Delta \mathrm{W}_{\mathrm{s}}\right)+\mathrm{C}_{0}+\left(\mathrm{S}_{0}-\Delta \mathrm{W}_{\mathrm{s}}\right)+\mathrm{G}_{0}=\gamma_{1} \mathrm{~V}_{1} \\
\left(\frac{\mathrm{W}_{0}}{\rho \mathrm{W}}+\frac{\Delta \mathrm{Ws}_{\mathrm{s}}}{\rho \mathrm{W}}\right)+\frac{\mathrm{C}_{0}}{\rho \mathrm{c}}+\left(\frac{\mathrm{S}_{0}}{\rho \mathrm{s}}-\frac{\Delta \mathrm{Ws}_{\mathrm{s}}}{\rho \mathrm{s}}\right)+\frac{\mathrm{G}_{0}}{\rho \mathrm{G}}+\mathrm{V}_{1} \cdot \frac{\mathrm{A}_{1}}{100}=\mathrm{V}_{1}
\end{gathered}
$$

式(1)および式(3)より

$$
\mathrm{V}_{1}=\frac{\mathrm{M}_{1}}{\gamma_{1}}=\frac{\mathrm{M}_{0}}{\gamma_{1}}=\frac{\gamma_{0} \cdot \mathrm{V}_{0}}{\gamma_{1}}
$$

式(4)を $\Delta \mathrm{W}_{\mathrm{s}}$ について解くと,

$$
\Delta W_{S}=\frac{\frac{\gamma_{0}}{\gamma_{1}} \cdot V_{0} \cdot\left(1-\frac{A_{1}}{100}\right)-V_{0} \cdot\left(1-\frac{A_{0}}{100}\right)}{\frac{1}{\rho w}-\frac{1}{\rho s}}
$$

単位水量Wは, 以下の式(7)より算出される.

$$
\mathrm{W}=\left(\gamma_{1} / \gamma_{0} \mathrm{~V}_{0}\right)\left(\mathrm{W}_{0}+\Delta \mathrm{W}_{\mathrm{S}}\right)
$$

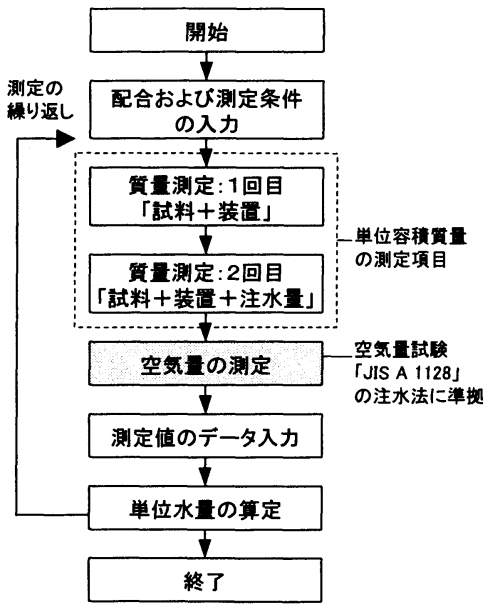

図-2 単位水量の測定フロー

\section{（3）測定手順および装置}

測定前の準備作業として，まずエアメー夕装置自体の 容積と質量を測定する．また，骨材中の空隙が空気量の 測定結果に及ぼす影響を補正するため，骨材修正係数を 求めておくことが望ましい.

JIS R 5201-1997「セメントの物理試験方法」によれば, セメントの密度は通常, 鉱油を用いて測定する. しかし, 単位容積質量を求める場合には，セメントの密度として 鉣油の代わりに水で試験した值を用いることの必要性が 指摘されている ${ }^{13)}$. 以下, 水を用いて測定したセメント の密度を湿潤密度と呼称する，なお，試験方法は鉱油を 水に置き換え，その他はJIS R 5201-1997に準拠する. ま た，この場合，セメントの水和反応が測定結果に影響を 及ぼさないことを実験により確認している33.

エアメー夕法による単位水量算定手順を図-2 に示す. まず, エアメータ中の試料の質量を測定する. その後, 蓋と試料表面との空間部分に水を満たした装置の質量を 測定する.これらの結果より単位容積質量を算出する.

次に, 空気量試験を「JIS A 1128-1999」の注水法に準 じて測定を行う. 単位水量は, これらの単位容積質量と 空気量の測定値を用い前節で示した式(7)から算定する.

\section{（4）高精度エアメー夕装置の概要}

単位容積質量および空気量の測定精度を高めるために 製作したエアメー夕装置の概要を写真-1 に示す．なお, 汎用のワシントン型エアメータと区別するために，本装 置を以下, 高精度エアメー夕装置と呼称することとする. 本装置は, 容器内の試料の圧力を測定する圧力計測部, 質量を測定する台はかりおよびこれらの測定結果から空 気量と単位容積質量を演算する制御部から構成される.

圧力の計測は, 従来のブルトン管式に代えてデジタル 式圧力計を用いている. また, 圧力計と台はかりによる 


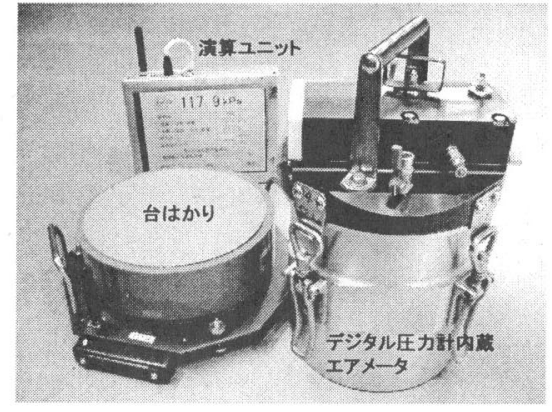

写真-1 高精度エアメー夕装置

測定データは, エアメータ本体とは独立した制御部に無 線で送信され，ディスプレイ画面上に空気量と単位容積 質量の測定結果が表示される. さらに, エアメータ本体 の蓋は, 注排水口を蓋の両端に配置し, 蓋の内面に沿つ て注水口から排水口に向かって気泡が移動，排出しやす いように勾配を付けた形状としている.

高精度エアメータ装置は, JIS A 1128-1999「フレッシ ユコンクリートの空気量の圧力による試験方法」と同じ 原理により空気量を測定する．ただし，ワシントン型エ アメータは, 初圧力を $100 \mathrm{kPa}$ 調整し圧力の減少量から 空気量を直読するのに対し, 高精度エアメータ装置は, デジタル式圧力計の測定値を制御装置に送信し，圧力と 空気量の関係を演算により求める.

すなわち，図-3 に示すように任意の初圧力に対する作 動弁開放後の平衡圧力と気泡容積との関係を予め制御装 置に設定しておき, 初圧力と平衡圧力から空気容積を算 定し，これを試料容積に対する百分率として式 (8) より 空気量を求めることになる. したがって, 初圧力を一定 に調整する必要はない.

$$
A_{1}=\frac{V_{a}}{V_{C}} \times 100
$$

\section{ここで, $V a ：$ 気泡容積 $\left(\mathrm{cm}^{3}\right)$}

$$
\mathrm{Vc}: \text { コンクリート試料容積 }\left(\mathrm{cm}^{3}\right)
$$

高精度エアメー夕装置による空気量の測定精度は, 最 小分解能が $0.1 \mathrm{kPa}$ である圧力計を用いた場合, 試料の容 積が7Lに対し理論上は $0.05 \%$ の測定精度が得られる.

\section{3．測定精度に及ぼす誤差要因}

\section{（1）測定装置の性能による影響}

エアメー夕法の場合, 単位水量の算定精度は, 台はか りの最小秤量と空気量の測定精度の影響を受ける.そこ で, 計測器の性能による単位水量の算定誤差を試算する. なお，算定誤差の検討には，コンクリートの配合試算例

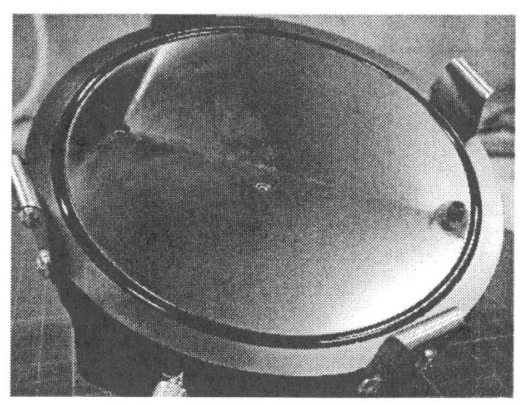

写真-2 エアメー夕蓋の内面形状

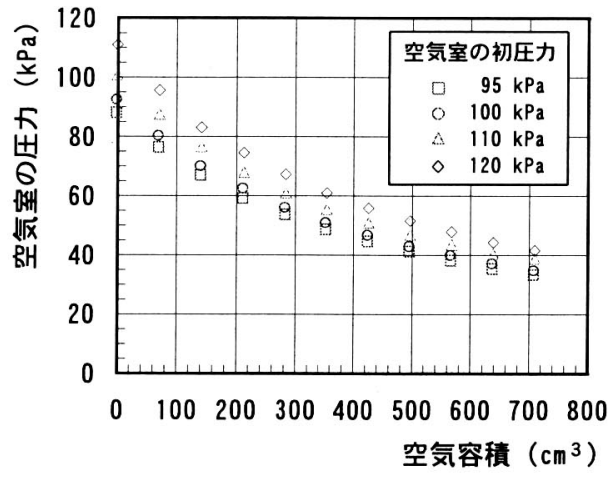

図-3 空気室の圧力と空気容積の関係

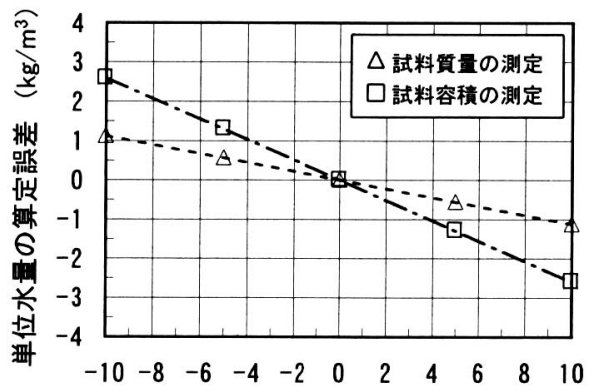

質量の測定誤差（g）

図-4 質量の測定誤差が単位水量算定結果に及ぼす影響

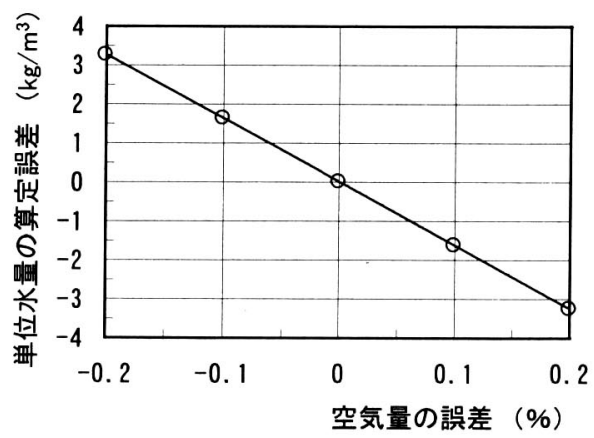

図-5 空気量の測定誤差が単位水量算定結果に及ぼす影䅧 
として, 水セメント比 $55.0 \%$, 細骨材率 $43.0 \%$, 単位水 量 $155 \mathrm{~kg} / \mathrm{m}^{3}$, セメントの密度 $3.16 \mathrm{~g} / \mathrm{cm}^{3}$, 細骨材の表乾密 度 $2.59 \mathrm{~g} / \mathrm{cm}^{3}$, 粗骨材の表乾密度 $2.66 \mathrm{~g} / \mathrm{cm}^{3}$ を用いた.

エアメータ法では, 単位容積質量を算定するために,

質量を2回測定する.1回目の測定では試料の質量, 2回目 の測定では, 試料の容積に対する測定誤差が単位容積質 量の算定に影響を及ぼす。そこで，まず単位容積質量を 測定するための質量測定の誤差が単位水量の算定結果に 及ぼす影響を試算した. 結果を図-4 に示す. 試料の質量 より容積の測定の方が水量算定結果に影響し， $\pm 8 \mathrm{~cm}^{3}$ で 単位水量として約 $2 \mathrm{~kg} / \mathrm{m}^{3}$ の誤差が生じる計算になる.

次に, 空気量の測定誤差が生じた場合に算定される単 位水量の変動試算結果を図-5 に示す.上記の容積による 誤差と同様に単位水量を $\pm 2 \mathrm{~kg} / \mathrm{m}^{3}$ の範囲で算定するには, 空気量は最低でも $0.1 \%$ 程度の精度が必要と計算される.

各計測装置の性能に起因する単位水量の算定誤差を表 示分解能として取り扱った場合, 台はかりとエアメー夕 の組合せから単位水量の算定誤差を計算した結果を図-6 に示す. 空気量の測定精度が $0.1 \%$, 台はかりの最小表示 が1 $\mathrm{g}$ の場合, 理論上は単位水量を $\pm 2 \mathrm{~kg} / \mathrm{m}^{3}$ 以内の精度で 算定することが可能と試算される.

\section{（2）材料密度の変動および許容誤差による影響} a）材料密度の変動の影響

コンクリートの各構成材料に対する密度の変動が単位 水量の算定に及ぼす影響について試算した結果を図-7 に示す．単位水量の誤差要因としては，水および骨材の 密度の影響が大きく,それぞれが個別に $\pm 0.01 \mathrm{~g} / \mathrm{cm}^{3}$ 変動 するだけで水量の誤差が土 $2 \mathrm{~kg} / \mathrm{m}^{3}$ 生じることになる.

\section{b）材料の計量誤差による影響}

コンクリート製造時に材料の計量に誤差が生じた場合, 当然ながら単位容積質量も設定值と異なった值になる. そこで, 各材料の計量誤差に起因する単位水量の算定誤 差を試算した．結果を図-8 に示す．いずれの材料に関し ても計量誤差がJIS A 5308-1998に規定されている許容 範囲の変動に対して，単位水量はそれぞれに約 $\pm 2 \mathrm{~kg} / \mathrm{m}^{3}$ の範囲内で変動するものと計算される.

\section{c）コンクリートの製造段階で許容される誤差範囲}

各材料の計量值がJIS A 5308-1998に規定された許容 範囲内で変動した場合に算定される単位水量の変動範囲 を試算した，また，密度も併せて变動すると仮定し，各 材料の密度をそれぞれ $\pm 0.02 \mathrm{~g} / \mathrm{cm}^{3}$ 変動させた場合につ いても試算した。

示方配合上の単位水量とこれら各種要因の変動から算 定される単位水量の関係を図-9に示す。単位水量は, 計 量誤差の影響により約 $\pm 5 \mathrm{~kg} / \mathrm{m}^{3}$ ，さらに各材料密度の設 定䛊差による影響を併せると最大で約 $\pm 12 \mathrm{~kg} / \mathrm{m}^{3}$ の誤差 を生じる可能性があると試算される.

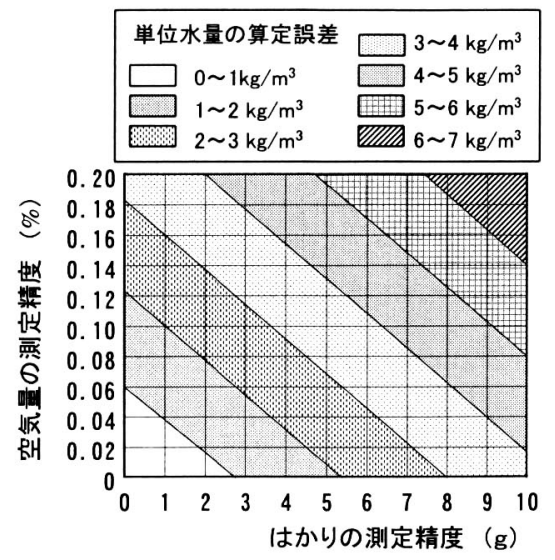

図-6 はかりと空気量の測定精度の組合せが 単位水量の算定誤差に及ほす影響

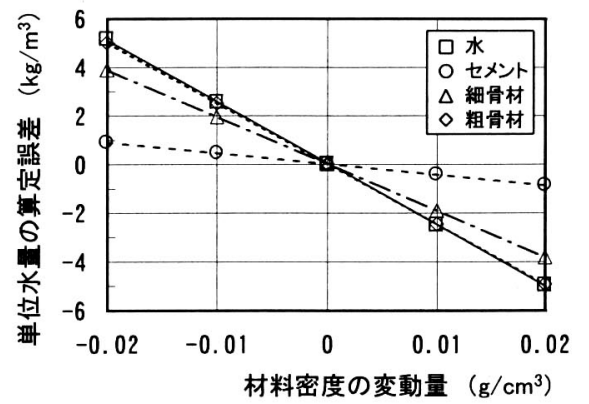

図-7 材料密度の変動が単位水量算定結果に及ぼす影響

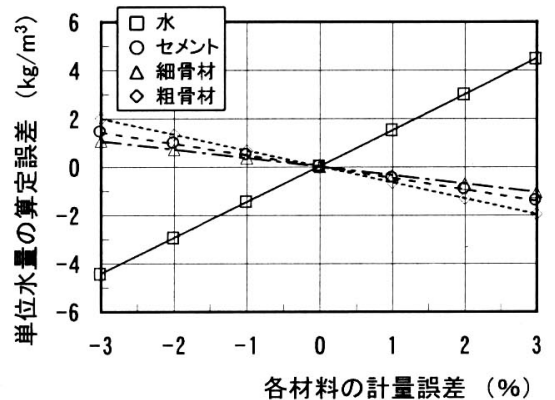

図-8 材料計量誤差が単位水量算定結果に及ぼす影響

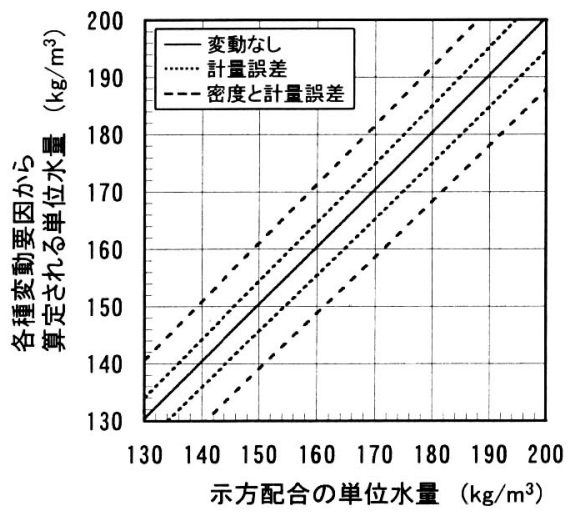

図-9 コンクリート製造時に想定される単位水量の誤差 
表-2 単位水量算定精度の検証に用いたコンクリート用材料の品質

\begin{tabular}{|c|c|c|c|}
\hline 材 料 & 記号 & 種 類 & 物 性 \\
\hline セメント & $\mathrm{C}$ & $\begin{array}{l}\text { 普通ポルトランド } \\
\text { セメント }\end{array}$ & $\begin{array}{l}\text { 密度 : } 3.16 \mathrm{~g} / \mathrm{cm}^{3} \text {, 比表面積 : } 3270 \mathrm{~cm}^{2} / \mathrm{g} \\
\text { 湿潤密度 }: 3.22 \mathrm{~g} / \mathrm{cm}^{3}\end{array}$ \\
\hline 細骨材 & S & 陸砂 & 表乾密度 : $2.62 \mathrm{~g} / \mathrm{cm}^{3}$, 吸水率 : $1.83 \%$, F.M. : 2.79 \\
\hline \multirow{2}{*}{ 粗骨材 } & G & 砕石 & 表乾密度: $2.66 \mathrm{~g} / \mathrm{cm}^{3}$, 吸水率 : 0.68\%, F.M. : 6.61 \\
\hline & $\mathrm{Gb}$ & ф20ガラスビース & 表乾密度 : $2.50 \mathrm{~g} / \mathrm{cm}^{3}$, 吸水率 : $0.02 \%$ \\
\hline 混和㓣 & WR & $\mathrm{AE}$ 減水剈 & リグニンスルホン酸化合物及びポリオール複合体 \\
\hline 練混ぜ水 & w & 上水道水 & 密度 : $1.00 \mathrm{~g} / \mathrm{cm}^{3}$ \\
\hline
\end{tabular}

表-3＼cjkstart実験に用いたモルタルおよびコンクリートの示方配合

\begin{tabular}{|c|c|c|c|c|c|c|c|c|c|c|c|}
\hline \multirow{2}{*}{ 記号 } & \multirow{2}{*}{ 種 類 } & \multirow{2}{*}{$\begin{array}{c}\text { 空気量 } \\
\text { (\%) }\end{array}$} & \multirow{2}{*}{$\begin{array}{l}\text { W/C } \\
(\%)\end{array}$} & \multirow{2}{*}{$\begin{array}{l}\text { s/a } \\
(\%)\end{array}$} & \multicolumn{5}{|c|}{ 単位量 $\left(\mathrm{kg} / \mathrm{m}^{3}\right)$} & \multirow{2}{*}{$\begin{array}{c}\text { WR } \\
(\mathrm{C} \times \%)\end{array}$} & \multirow{2}{*}{$\begin{array}{c}\text { セメントの湿浱 } \\
\text { 密度で補し正した } \\
\text { 単位容積賈量 } \\
(\mathrm{kg} / \mathrm{L})\end{array}$} \\
\hline & & & & & W & C & $S$ & G & $\mathrm{Gb}$ & & \\
\hline$M-1$ & モルタル & - & 40.0 & - & 296 & 741 & 1129 & - & - & - & 2276 \\
\hline$M-2$ & - & - & 30.0 & - & 240 & 800 & - & 1348 & - & - & 2399 \\
\hline$M-3$ & - & - & 40.0 & - & 296 & 740 & - & - & 1173 & - & 2220 \\
\hline$C-1$ & コンクリート & 4.5 & 50.0 & 42.0 & 145 & 290 & 790 & 1108 & - & 0.25 & 2337 \\
\hline$c-2$ & コンクリート & 4.5 & 50.0 & 45.0 & 150 & 300 & 837 & 1039 & - & 0.25 & 2330 \\
\hline$c-3$ & コンクリート & 4.5 & 50.0 & 45.0 & 162 & 324 & 814 & 1010 & - & 0.25 & 2315 \\
\hline$C-4$ & コンクリート & 4.5 & 45.0 & 48.0 & 175 & 389 & 826 & 909 & - & 0.25 & 2304 \\
\hline
\end{tabular}

\section{d）温度による影響}

現場でエアメータ法を適用する場合, 容器とコンクリ 一ト試料に温度差が生じる場合がある.そこで, 測定容 器の熱膨張・収縮による単位水量の算定誤差の影響につ いて試算した．鋼製エアメー夕容器とコンクリートの線 膨張係数を同一 $\left(10 \times 10^{-6} /{ }^{\circ} \mathrm{C}\right)$ とし試料量は約 $6 \mathrm{~L}$ とた.

試料と容器の温度差が $\pm 10^{\circ} \mathrm{C}$ 場合, 容積の変動量は $\pm 1.8 \mathrm{~cm}^{3}$ となる.この容積変化による単位容積質量の変 動は約 $\pm 0.03 \%$, 単位水量換算で約 $\pm 0.05 \mathrm{~kg} / \mathrm{m}^{3}$ となる. したがって, コンクリート試料と容器の温度差が極端に 大きくなければ単位水量の誤差に及ぼす影響は小さいと いえる. なお, 試料を容器に投入すると, 熱伝導により 温度が均等化して誤差はさらに小さくなるので, 実用上 はほとんど無視できるものと考えられる.

\section{4. エアメータ法による単位水量測定精度の 実験的検証}

（1）測定装置に起因する単位水量測定精度の検証

使用材料の計量誤差およびサンプリング誤差が実用上 無視できる条件下でコンクリートを製造し，単位容積質 量と空気量から単位水量を算定する場合の試験装置に起 因する測定精度について検証した。
使用材料を表-2, 示方配合を表-3 に示す. モルタルや 各種配合のコンクリート以外に, 細骨材の代わりに内部 吸水の影響を受けないガラスビーズを使用した場合や骨 材として粗骨材だけを使用した場合についても試験した. また，単位容積質量および空気量の測定には，高精度工 アメータ装置を使用した.

モルタルや各種の擬似コンクリートを対象とした場合 の単位容積質量と空気量の測定結果を図-10 に, 単位水 量の算定結果を図-11 に示す.いずれの場合の測定値と も単位容積質量と空気量の関係から求まる理論値とほぼ 一致し，単位水量は設定值に対して $-1.8 \sim+2.0 \mathrm{~kg} / \mathrm{m}^{3}$ の 範囲で算定される結果となった。

各種配合のコンクリートを対象とした場合の単位容積 質量と空気量の関係を図ー12 に, 単位水量の算定結果を 図-13 に示す. 単位水量を145 $175 \mathrm{~kg} / \mathrm{m}^{3}$ の範囲で変化 させた場合も測定値はいずれも単位容積質量と空気量の 関係から求まる理論值とほぼ一致する結果となった。 ま た，単位水量はいずれの配合についても設定值に対して 約 $\pm 2 \mathrm{~kg} / \mathrm{m}^{3}$ の範囲で精度良く算定される結果が得られた.

秤の最小秤量が $1 \mathrm{~g}$, 空気量の計測精度が $0.1 \%$ 装置を 用いた場合, 装置の性能から想定される単位水量の誤差 が約 $\pm 2 \mathrm{~kg} / \mathrm{m}^{3}$ であることを考慮すると，実測デー夕は試 算結果とほぼ同程度の誤差であり，エアメー夕法による 実質的な測定精度が検証できたものと考えられる。 


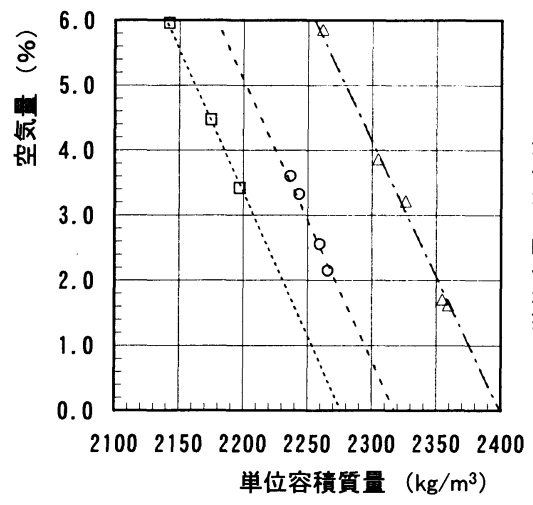

図-10 単位容積質量と空気量

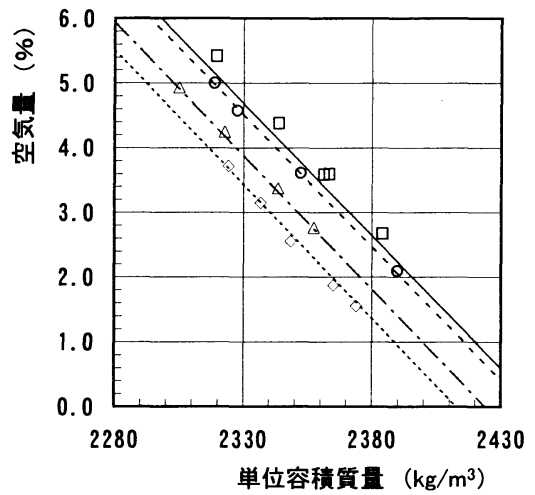

図-12 コンクリートの単位容積質量と空気量

\section{（2）現場荷卸し時における単位水量測定例}

現場荷卸し時にエアメータ法を適用し，コンクリート の単位水量を測定した. 単位容積質量と空気量の測定に はワシントン型のエアメータを使用し, 注水法により試 験を実施した。

測定対象のコンクリートは, 水セメント比 $48.5 \%$, 細 骨材率 $42.5 \%$, 単位水量 $155 \mathrm{~kg} / \mathrm{m}^{3}$, セメントは高炉セメ ント B種（湿潤密度 $3.10 \mathrm{~g} / \mathrm{cm}^{3}$ ）を用いた.

空気量と単位容積質量の測定結果を図-14に, 単位水 量の算定結果を図-15 に示す. 終日にわたって測定した 結果, 荷卸し時のフレッシュコンクリートの単位水量は, 打設開始時には計画値を下回ったが, その後計画値より 最大で約 $15 \mathrm{~kg} / \mathrm{m}^{3}$ 多い場合も見受けられ, 後半は徐々に ほぼ設定值に近く推移する結果となった.

エアメー夕法による単位水量の測定は, 汎用のエアメ 一夕装置を転用できることから, 測定装置の取扱い操作 を新たに習熟する必要がなく, 従来の品質試験の延長上 での測定が可能である. また, 1 回当たりの測定時間も 約5分程度と比較的短く, 迅速に結果が求められる.

以上のことから，エアメー夕法は，製造段階での単位 水量管理や現場での受入れ検查などに対しても簡便で 迅速な方法として有用であると考えられる.

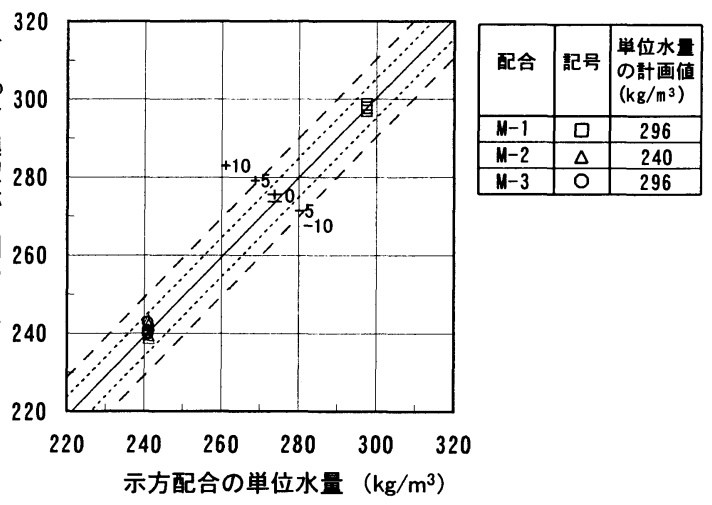

図-11 単位水量の算定結果

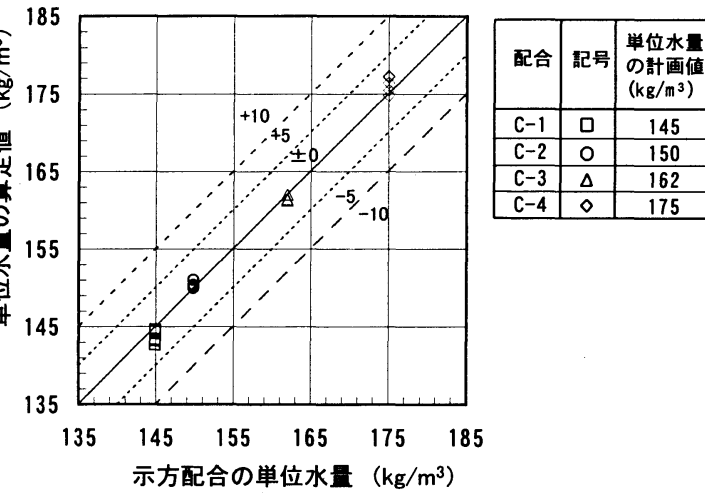

図-13 単位水量の算定結果

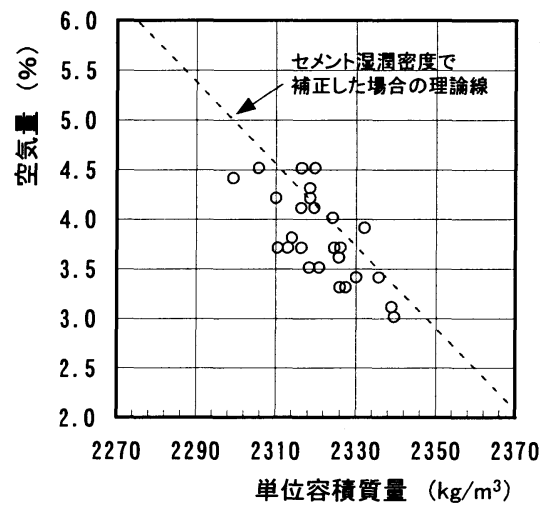

図-14 単位容積質量と空気量

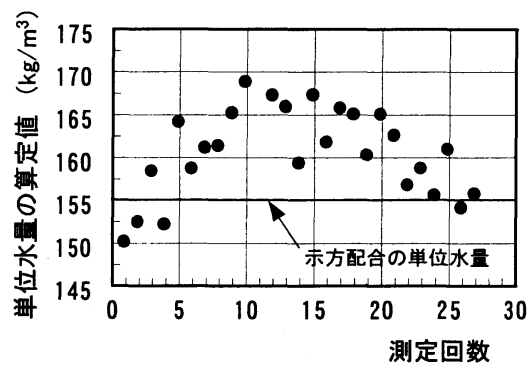

図-15 単位水量の算定結果 


\section{5. まとめ}

空気量と単位容積質量からフレッシュコンクリート の単位水量を算定する方法に関して検討した. 本論文の 範囲内で得られた知見を以下に示す.

（1）エアメータ法による単位水量の算定方法によれば, 測定装置の性能として, はかりの最小秤量が $1 \mathrm{~g}$, 空気 量の測定精度が $0.1 \%$ 装置を用いた場合, 材料の計量 誤差やサンプリングによる誤差がない条件では, 約 \pm 2 $\mathrm{kg} / \mathrm{m}^{3}$ の精度で単位水量を算定することができる.

（2）コンクリート製造時における細骨材や粗骨材の湿 潤密度の変動や空気量の測定誤差は, 単位水量の算定誤 差に及ぼす影響が大きい。

（3）エアメー夕法は, 従来の空気量試験に併せて単位水 量を算定できること, また， 1 回の測定時間が5分程度 で完了することから, 荷卸し時における簡便かつ迅速な 単位水量測定方法として有用である.

\section{参考献}

1）笠井芳夫, 池田尚治 : コンクリート試験方法 (上), 技 術書院, 1993 .

2）丸嶋紀夫, 黒羽健跲, 並木哲, 久保田浩 : 水中質量法 によるフレッシュコンクリートの単位水量試験方法, コンクリート工学年次論文報告集, Vol. 20-2, pp. 313 $-318,1998$.

3）中村博之, 十河茂幸 : フレッシュコンクリートの空気 量と単位容積質量の測定結果による配合推定方法の適 用, コンクリート工学年次論文集, Vol. 23-2, pp. 325 $-330,2001$.

4）河野広隆, 片平 博 : フレッシュコンクリートの単位 水量迅速測定法に関する実験的研究, 土木研究所資料 第3657号, 1999.
5）河野広隆, 加藤俊二, 田中和秀, 片平博 : 高温加熱に よるフレッシュコンクリートの単位水量迅速推定方法 の検討, 土木研究所資料，第 3611 号， 1999.

6）友沢史紀, 杵田佳寛, 棚野博之: 高周波加熱装置を用 いたフレッシュコンクリートの単位水量迅速試験方法 の開発, 日本建築学会構造系論文報告集, pp. 1-7, 1989.

7）中村博之, 平田隆祥, 十河茂幸 : 減圧乾燥によるフレ ッシュコンクリートの単位水量検査方法に関する研究, セメントコンクリート論文集，No. 54，pp. 596-601， 2000.

8）清水昭之, 梅津裕二 : フレッシュコンクリート中の水 量推定のための簡易試験方法に関する研究 (その 3 ), 日本建築学会学術講演概要集, pp. 107-108, 1987.

9）南條毅一, 宮下有生, 辻村博美: 単位水量試験方法(塩 化物イオン法)の提案, 第10回生コン技術大会集, pp. 251-256, 1999.

10）斎充, 伊木純一, 沓掛文夫 : 静電容量型水分計による フレッシュコンクリートの単位水量推定, コンクリー 卜年次論文報告集, Vol.20-2, pp. 307-312, 1998.

11）瀬古繁喜, 田村博, 鈴木一雄, 熊原義文： R I 水分計 を用いたポンプ配管中のコンクリートの水量連続モニ タリング，コンクリート年次論文報告集, Vol.20-1, pp. 125-130, 1998.

12）若松岳, 近松竜一, 平田隆祥, 十河茂幸 : 現場におけ るフレッシュコンクリートの単位水量管理方法に関す る提案, コンクリート年次論文報告集, $\mathrm{V}_{0} 1.20-1, \mathrm{pp}$. 107-112, 1998.

13）片平 博: フレッシュコンクリートの単位水量, コン クリート工学, Vol.39-5, pp.64-67, 2001.

(2002. 2.14受付)

\title{
STUDY ON MEASUREMENT METHOD OF WATER CONTENT IN CONCRETE WITH AIR CONTENT AND DENSITY OF CONCRETE MIXTURE
}

\author{
Hiroyuki NAKAMURA, Ryuichi CHIKAMATSU and Shigeyuki SOGO
}

\begin{abstract}
Water content is a critical parameter strongly affecting the durability of concrete structures. Therefore, a simple and accurate measurement is desired for quality inspection of as-delivered concrete. This paper describes a calculating method of water content of fresh concrete with the density and air content measurements. The fluctuation of material densities and the measurement error of air content were found to strongly affect the calculation results. However, the water content could be calculated with an accuracy of $\pm 2 \mathrm{~kg} / \mathrm{m}^{3}$ by precisely measuring the air content and acculately determining the density of concrete. With a measuring time of 5 minutes, the proposed method was proven highly applicable to field measurement of water content of concrete.
\end{abstract}

